\title{
Temporal Dynamics of Rice Production and Import in Nepal
}

\author{
Samaya Gairhe ${ }^{1 @}$, Devendra Gauchan² and Krishna Prasad Timsina ${ }^{3}$ \\ ${ }^{1}$ Nepal Agricultural Research Council, Kathmandu, Nepal @: samaya43@gmail.com \\ (iD https://orcid.org/0000-0002-1735-3334 \\ ${ }^{2}$ Alliance of Bioversity International and CIAT, Kathmandu, Nepal; d.gauchan@cgiar.org \\ (Dhttps://orcid.org/0000-0002-3607-8841 \\ ${ }^{3}$ National Agricultural Policy Research Centre, Khumaltar, Lalitpur, Nepal; krishnatimsina2000@gmail.com \\ (iD https://orcid.org/0000-0003-4005-7039
}
Received 16 August, 2020, Revised 15 January, 2021, Accepted 27 March, 2021, Published 30 April, 2021
Scientific Editors: Hari K Shrestha, Vijayachandra Reddi S, Bhumi Kafle
Copyright (C) 2021 NARC. Permits unrestricted use, distribution and reproduction in any medium provided the original work is properly cited.
The authors declare that there is no conflict of interest.

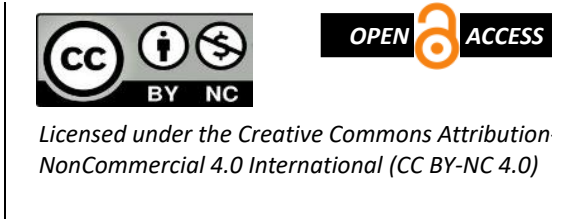

\section{ABSTRACT}

Rice is a principal food crop for ensuring national food security and improving the livelihoods of the people in Nepal. To understand and analyse temporal dynamics of rice production and import, a study was carried out by using secondary data during the period from 2009 to 2018. The objectives of the study were to analyses temporal changes and dynamics of rice production and import in Nepal. The study used Compound growth rate and Markov chain analysis to assess the pattern of temporal changes in production and import of rice in Nepal for the last one decade. The synthesis of the analysis is presented in both tabular and graphic forms. The results revealed that Nepal is importing rice in increasing trend and not being able to meet national demands despite some increase in rice production and productivity in the last decade. Imports of rice were found in four harmonized system codes from 18 countries and the value of rice import is mounting in recent years. In addition, Compound growth rate analysis showed that the rice import quantity and value were increasing at the rate of 24.48 and 38.11 percent per annum respectively, while production growth was hovering below less than $2 \%$ per annum. The higher growth rate of value than quantity showed that mainly import is concentrated on fine and aromatic rice. Further, the study also reveals the direction of trade using Markov chain analysis, which shows that among selected countries, two countries India and the USA were more stable rice exporters to Nepal while China, Thailand, and Italy were less stable. The study implies that import substitution can be done by increasing productivity with increase use of high yielding hybrids and fine and aromatic rice.

Keywords: Import, milling efficiency, production, rice, temporal change

\section{सारांश}

धान नेपालमा पोषण सुरक्षा र जीविकोपार्जनको लागि महत्त्वपूर्ण बाली हो । धानको उत्पादन तथा आयातमा समयको गतिशिलताका आधारमा बुझन र विश्लेषण गर्न २००९ देखि २०१६ सम्मको तथ्यांक प्रयोग गरि एक अध्ययन गरिएको थियो । यस अध्ययनको उदेश्य नेपालमा समयका आधारमा धान उत्पादन र आयातको परिवर्तन र गतिशिलता विश्लेषण गर्ने रहेको थियो । यसका लागि विश्लेषण गर्न Compound growth rate ₹ Markov chain analysis प्रयोग गरि विगत एक दशकमा धान उत्पादन तथा आयातको ढांचामा समयका आधारमा भएको परिवर्तनलाई मुल्यांकन गरिएको थियो । अध्ययनको संश्लेषण तथा निचोड तालिका र चित्रको रुपमा प्रस्तुत गरिएको छ। नातिजानुसर विगतको दशकमा धानको उत्पादन तथा उत्पादकत्वमा केहि सुधार भएपनि रास्ट्रिय मागलाई पूर्ति गर्न नसकेका कारण आयात निरन्तर बढ्ने क्रमा रहको देखिन्छ। नेपालमा धानको आयात १६ देशबाट $\gamma$ वटा कोड प्रणाली प्रयोग गरि आयात हुने र यसको मान केहि बर्ष यता शिखर चुम्ने हिसाबले बढेको देखिन्छ । Compound growth rate को नातिजानुसर धान आयातको मात्रा र मान ऋमश २४.४५ र ३५.११ प्रतिशतका दरले प्रतिवर्ष बढेको देखिन्छ तर सोहि समयमा उत्पादन वृद्धिदर २ प्रतिशत प्रति बर्ष भन्दा कममा अड्किएको देखिन्छ । धान आयातमा "मात्रा" भन्दा धैरै 'मानको' वृद्धिले मसिनो तथा बास्नादार धान बढि आयात भएको बुझिन्छ, 1 Markov chain analysis ले ब्यापारको दिशा देखाउने र नातिजानुसर भारत र संयुक्त राज्य अमेरिका धैरै स्थिर नेपालका लागि धान निर्यातकर्ता रहेको तर चिन, थाईल्याण्ड, इटाली कम 
स्थिर मुलुक रहेको पाईयो । त्यसैले धानको आयात प्रतिस्थापन गर्न धैरै उत्पादन दिने बर्णशंकर र मसिनो तथा बास्नादार धानका जातहरुको विकास गरि उत्पादकत्व वृद्धि गर्नु पर्ने देखिन्छ।

\section{INTRODUCTION}

Rice is the major staple food in Nepal in terms of area, production, and food security of the people. It contributed to about 20.8 percent and 5.74 percent of Agricultural Gross Domestic Product (AGDP) and Gross Domestic Product (GDP) of the country, respectively in 2018 (MoF 2018). Rice is planted in the area of 1,469,545 ha with an average productivity of 3.50 t/ha in 2018 (MoALD 2018) with increase of nearly $1 \mathrm{t} / \mathrm{ha}$ from a decade ago in 2007/08 (MoALD 2009). The crop is grown in different ecological environments in Nepal from the lowland in Terai (50-300 m asl) to the Hills (>300-1500 m asl) and Mountains (>1500-3000). Rice productivity is low in Nepal as compared to global average productivity of ( $4.0 \mathrm{mt} / \mathrm{ha}$ ) due to poor investment in research and technological development (Gauchan and Pandey 2011). The current production is not sufficient to meet the demand of growing population and ensure food security in the country (Shrestha et al 2021). Nepal used to be a net exporter of rice from 1960-1980s and during the 1960s the country was every year exporting up to $\$ 45$ million worth of rice to India. However, in the year $2015 \mathrm{Nepal}$ had imported 531,000 tons of rice worth $\$ 210$ million from India (Nepali Times 2019). Five years of food import data of Nepal showed that the import value has increased from NPRs. 44.43 billion in 2009-10 to NPRs. 127.51 billion in 2013-14 (Gairhe et al 2018). Even though there is increased productivity of rice over a period, Nepal has spent NPRs 33.33 billion to import rice in 2018 (TEPC 2018). This is $26 \%$ of the total food import in the country. Rice import is galloping recently because of insufficient production to increased population based on heterogenous preference (Gairhe et al 2020). In addition to population growth; urbanization, change in food habit towards rice mainly of fine and aromatic rice including flow of cheaper price of rice from India are the main drivers of rice imports in Nepal (Pudasainee et al 2018). Due to increasing road network and per capita income of Nepalese people, the demand of rice has also increased recently (Tripathi et al 2018). The chasm between production and import is increasing and the country is not being able to meet national demands despite some increase in rice production and productivity in the last one decade. However, information is limited about the pattern of temporal changes and dynamics of rice production and imports in Nepal. At this back drop, this study aims to understand and analyses temporal changes and dynamics of rice production and imports in Nepal.

\section{MATERIALS AND METHODS}

\section{Data Sources}

Time series data on area, production and yield of rice were collected from secondary sources published by government mainly from Statistical Information of Nepalese Agriculture of the Ministry of Agricultural and Livestock Development (MoALD) and Center Bureau of Statitics, National Planning Commitiions. The import and export data are collected from Trade and Export Promotion Centre of the Ministry of Industry, Commerce and Supplies (MoICS). The analyses of the data were done by using 10 years of data from 2009 to 2018 on area, production, productivity and import of rice. Compound growth rate and Markov chain analysis were used for analysis of data and are presented in both tabular and graphic forms.

\section{Compound Growth Rate (g) Analysis}

Past performance of any variable is indicated by growth of particular variables. Growth of any variable indicates its past performance. The study of growth is frequently used in economic studies to see the trend of a particular variable over a time period. It visibly indicates the performance of the variable under concern, thus can be interpreted for policy decisions. Exponential growth function was used to estimate the growth in the area, production, productivity, value and quantity of rice import in Nepal, which is given below:

$$
\mathrm{Y}_{\mathrm{t}}=\mathrm{ab}^{\mathrm{t}} \mathrm{u}_{\mathrm{t}}
$$


Where,

$\mathrm{Y}_{\mathrm{t}}$ : Dependent variable for which growth rate was estimated

a: Intercept

b: Coefficient of regression $(1+\mathrm{g})$

t: Years which takes values, $1,2, \ldots \ldots \ldots \ldots, \mathrm{n}$

$\mathrm{u}_{\mathrm{t}}$ : Disturbance term for the year $\mathrm{t}$

For the estimation purpose, the equation was transformed into log linear form and ordinary least square (OLS) technique was used for estimation. The compound growth rate $(\mathrm{g})$ in percentage was then computed from the relationship:

$\mathrm{g}=\{\text { Antilog of }(\ln \mathrm{b})-1\}^{\times 100}$

Regression coefficient significance was tested by using the student's' test.

\section{Markov Chain Analysis}

The trade directions of rice import from 2009 to 2018 were analyzed using the first order Markov chain approach. Markov chain analysis is an application of dynamic programming to the solution of a stochastic decision process that can be defined by a finite number of states (Padberg 1962). The dynamic nature of trade patterns, direction of trade growth, and predicting the future values of growth can be measured using Markov chain analysis (Bagalkoti et al 2019; Sheelpa shree et al 2017).

Central to Markov chain analysis is the estimation of the transitional probability matrix P. The elements Pij of the matrix P indicates the probability that import will switch from country $i$ to country $j$ with the passage of time. The diagonal elements of the matrix measure the probability that the import share of a country will be retained. Hence, an examination of the diagonal elements indicates the loyalty of an exporting country to a particular country's imports.

In the context of the current application, structural changes were treated as a random process with selected importing countries. The average imports to a particular country was considered to be a random variable which depends only on the past exports to that country, which can be denoted algebraically as

$$
E_{j t}=\sum_{i=1}^{r} E_{i t-1 *} P_{i j}+e_{j t}
$$

Where,

$E_{\mathrm{jt}}=$ Imports to Nepal from $\mathrm{j}^{\text {th }}$ country during the year $\mathrm{t}$.

$\mathrm{E}_{\mathrm{it}-1}=$ Imports from $\mathrm{i}^{\text {th }}$ country during the period $\mathrm{t}-1$.

$P_{i j}=$ Probability that the imports will shift from $i^{\text {th }}$ country to $\mathrm{j}^{\text {th }}$ country.

$\mathrm{e}_{\mathrm{jt}}=$ The error term which is statistically independent of $\mathrm{E}_{\mathrm{it}-1}$.

$\mathrm{t}=$ Number of years considered for the analysis

$r=$ Number of exporting countries

The transitional probabilities $\mathrm{P}_{\mathrm{ij}}$ which can be arranged in a $(\mathrm{c} * \mathrm{r})$ matrix have the following properties.

$$
\begin{aligned}
& \mathrm{O} \leq \mathrm{P}_{\mathrm{ij}} \leq 1 \\
& \sum_{\mathrm{i}=1}^{\mathrm{n}} \mathrm{P}_{\mathrm{ij}}=1 \text { for all } \mathrm{i}
\end{aligned}
$$

Thus, the expected import shares of each country during period ' $t$ ' were obtained by multiplying the import from these countries in the previous period ( $\mathrm{t}-1)$ with the transitional probability matrix.

To estimate the transitional probabilities of the Markov chain model Minimum Absolute Deviations (MAD) estimation procedure was employed, which minimizes the sum of absolute deviations. The conventional linear programming technique was used, as this satisfies the properties of transitional probabilities of non-negativity restrictions and row sum constraints in estimation. The linear programming formulation is stated as:

$$
\text { Min } \mathrm{OP}^{*}+\mathrm{Ie}
$$

Subject to,

$$
\begin{aligned}
& \mathrm{XP}^{*}+\mathrm{V}=\mathrm{Y} \\
& \mathrm{GP}^{*}=1 \\
& \mathrm{P}^{*} \geq 0
\end{aligned}
$$


Where,

$0 \quad$ - is the vector of zeroes.

$\mathrm{P}^{*} \quad$ - is the vector in which probability $\mathrm{P}_{\mathrm{ij}}$ are arranged.

I - is an apparently dimensioned vector of quantity.

E - is a vector of absolute error (1 U 1).

$\mathrm{Y}$ - is the vector of import from each country.

$\mathrm{X}$ - is the block diagonal matrix of lagged values of $\mathrm{Y}$

$\mathrm{V}$ - is the vector of errors

$\mathrm{G} \quad$ - is the grouping matrix to add the row elements of $\mathrm{P}$ arranged in $\mathrm{P}^{*}$ to unity.

The value of diagonal elements indicates the probability of retention of the previous year values, while values in columns reveal probability of gain of a particular country from other countries, values in rows reveal probability that a country might lose to their countries share in respect of specific commodity imports. Similar methodology were used by Gairhe and Reddy (2012) to study the coffee export scenario in India, and Shilpa Shree et al (2017) to reveal the changing direction of export and import of dairy products in India.

\section{RESULTS}

Rice Area, Production and Productivity

Rice area, production, and productivity trend from 2009 to 2018 is shown in Figure 1. In the last one decade, a higher fluctuation in production and productivity is observed, while area remained rather stable. Production and productivity showed a slightly increasing trend however the area seemed to be decreasing over the years.

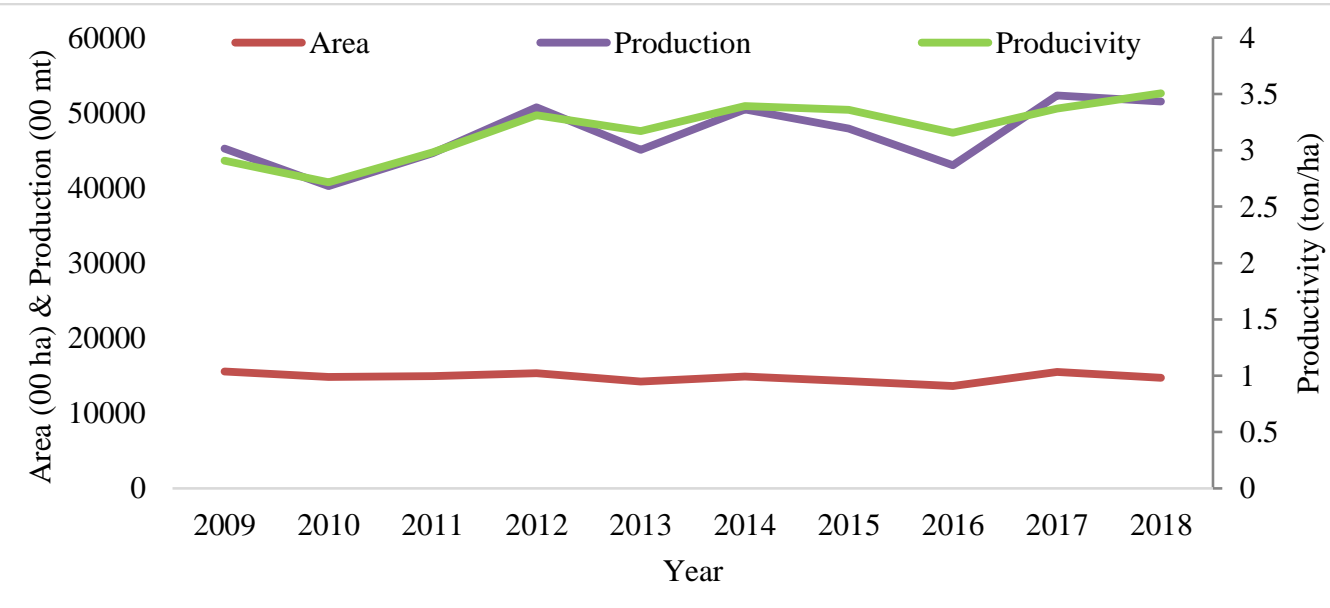

Figure 1. Trendline showing rice area, production, and productivity in Nepal from 2009 to 2018

Rice area, production, and productivity growth rate from 2009 to 2018 are shown in Table 1 . The result revealed that the rice production and productivity are increasing at the rate of 1.69 and 2.20 percent per annum respectively. However, the area seems to be decreasing but not statistically significant. At the same period the population of Nepal is increasing at the rate of 0.36 percent per annum.

Table 1. The compound growth rate of rice area, production, productivity and population in Nepal from 2009 to 2018

\begin{tabular}{lcccc}
\hline Parameters & Intercept & CGR & $\mathbf{R}^{\mathbf{2}}$ & P-value \\
\hline Area & 14.23 & -0.50 & 0.13 & 0.310 \\
\hline Production & 15.27 & $1.69^{*}$ & 0.33 & 0.080 \\
\hline Productivity & 10.25 & $2.20^{* * *}$ & 0.66 & 0.004 \\
\hline Population & 3.28 & $0.36^{* * *}$ & 0.59 & 0.009
\end{tabular}

Note: $* * * * *$ and $*$ indicates Significance at 1,5 and 10 percent level respectively 
The increase of production and productivity was obtained with the use of improved rice varieties and increased use of irrigation, and fertilizers (Gairhe et al 2020). Productivity improvement can be assured with development of high yielding hybrids and stress resilient varieties across the country. In addition, technological innovation has been playing a major role to increase production and productivity rather than other factors (Upadhyay et al 2009).

\section{Rice Production and Requirement in Nepal}

Rice production and requirement in Nepal from 2009 to 2017 are shown in Figure 2. The result revealed that the country has on an average 1 million metric ton of rice deficit than the current level of production despite some yearly variation. Some years, there was a low deficit with increased rice production (e.g. year 2012, 2014 and 2017), when the weather was favourable for timely planting and production with better crop management and use of improved production inputs (availability of improved seeds and chemical fertilizers) in the country. Over the last decade, the rice deficit is not narrowing due to low productivity growth of rice with the use of low use of technologies and inputs. Moreover, the rice productivity was low in 2010, 2013 and 2015 due to drought and floods in many parts of Nepal. Besides food, rice is also used as feed, seed, alcoholic beverages, and other uses of rice. Moreover; huge amount of rice loss or waste is observed during consumption. However; in terms of total aggregate edible cereals (rice, wheat, maize, millet, barley, buckwheat) production, the country produces surplus food that can meet the national requirement (Kaphle and Bist 2017).

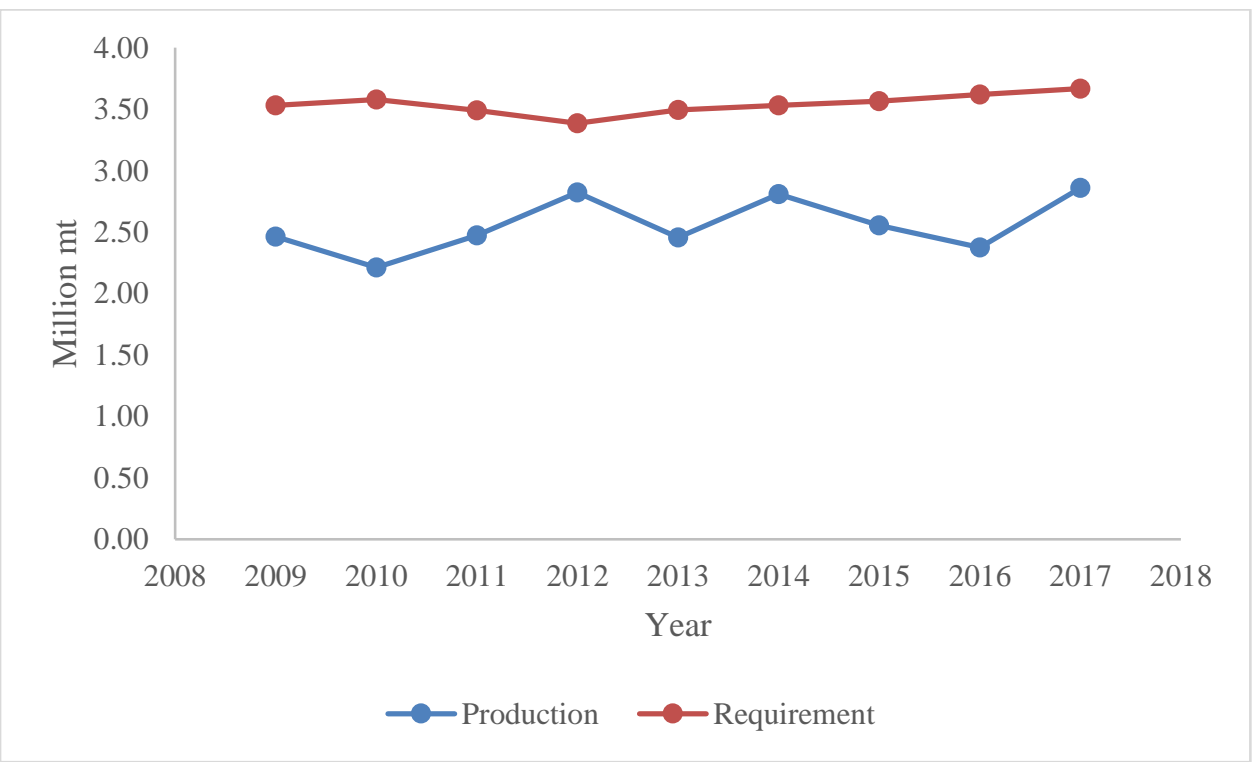

Figure 2. Rice production and requirement in Nepal from 2009 to 2017

\section{Rice Imports in Nepal}

Harmonized system code and different forms of rice import in Nepal is presented in Table 2. Mainly there are four harmonized system codes under which different rice forms are being imported in Nepal.

Table 2. Harmonized system and forms of rice import in Nepal

\begin{tabular}{ll}
\hline HS Code & Description \\
\hline 10061000 & Rice in the husk (paddy or rough) \\
\hline 10062000 & Husked (brown) rice \\
\hline 10063000 & Semi-milled or wholly milled rice, whether or not polished or glazed \\
\hline 10064000 & Broken rice \\
\hline
\end{tabular}

The Harmonized Commodity Description and Coding System generally referred to as "Harmonized System" or simply "HS" is a multipurpose international product nomenclature developed by the World Customs Organization (WCO). 
Rough rice or paddy is defined as rice in the husk after harvesting. Husked rice/brown rice is the rice from which only the husk has been removed retaining the bran layers and most of the germ together. Such rice is sometimes reflected as bran rice even though variations are having red or white bran coats. Milled rice is that from which husk, germ, and bran layers have been removed mechanically. White Rice/polished rice is that when the outer layers of bran are completely removed. Broken rice is formed from husked, milled or hand-pounded milled rice with grain size between 3/4th to 1/4th size of whole grain.

Countries from which different forms of rice are being imported in Nepal are shown in Table 3.

Table 3. Countries exporting rice to Nepal

\begin{tabular}{rlrlrl}
\hline S.N. & Countries & S.N. & Countries & S.N. & Countries \\
\hline 1 & India & 7 & Philippines & 13 & Korea \\
\hline 2 & USA & 8 & Bangladesh & 14 & Indonesia \\
\hline 3 & China & 9 & Vietnam & 15 & UK \\
\hline 4 & Thailand & 10 & Malaysia & 16 & Baharain \\
5 & Italy & 11 & Singapore & 17 & Canada \\
\hline 6 & Japan & 12 & Pakistan & 18 & Isle of man \\
\hline
\end{tabular}

The value of rice imports in Nepal from 2009 to 2018 is depicted in Figure 3. Nepal used to expense on rice around NRs 1.65 thousand million in 2009 and about NRs 33.33 thousand million in 2018. Slope of the trend line is steep and it can be observed that Nepal has invested a huge amount of money for rice imports in recent years.

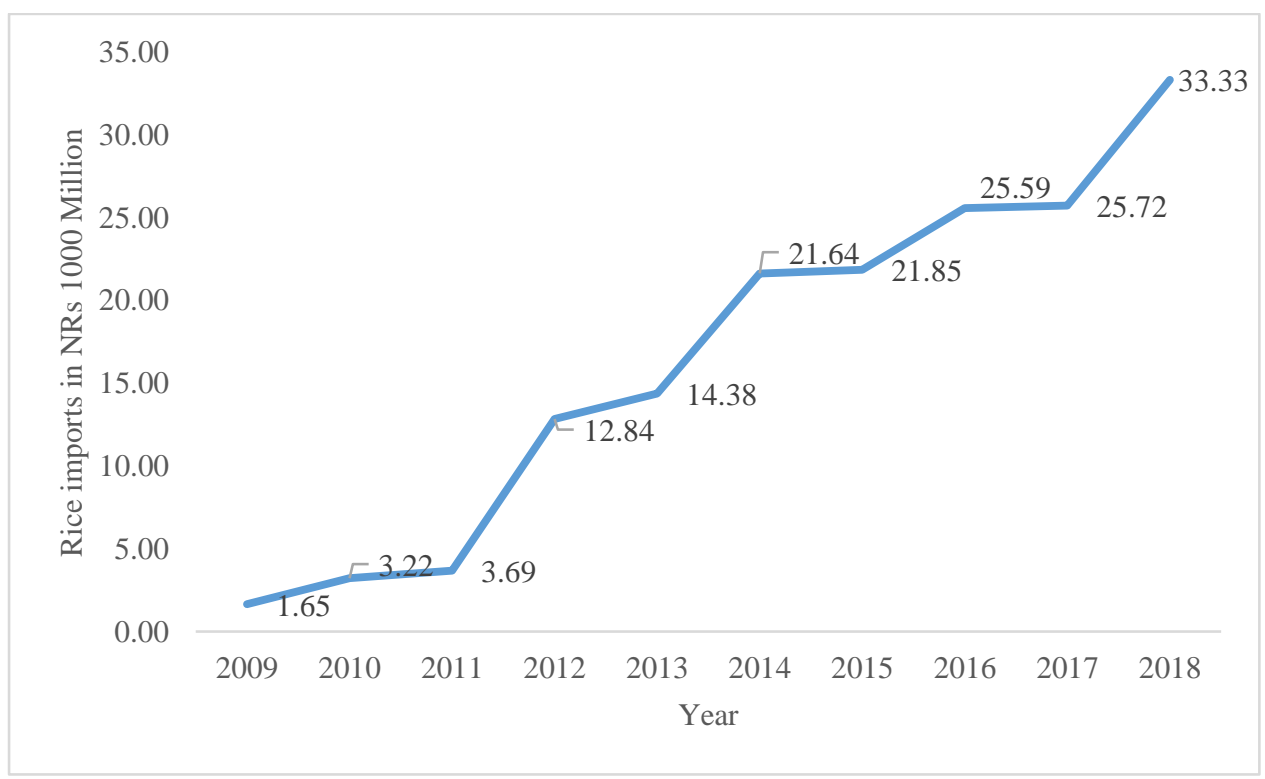

Figure 3. Trendline showing rice import in Nepal from 2009 to 2018

The increasing value of import of rice occurs due to the increasing demand for rice in the country particularly that of fine and aromatic rice with the increased remittance income and increase preference for high-quality premium rice (Kahple et al 2020). In addition, the change of food habits of people from coarse grains (maize, millet) to rice and increased connectivity to remote and rural hills and mountains in recent years has made easy and cheaper access of rice grains among rural populations for their increased consumption. However, reliable disaggregated data of volume and value of import of premium fine and aromatic rice is not available in Nepal. 
Different forms of rice import percentage from 2009 to 2018 is depicted in Figure 4. During these years, trend of paddy and broken rice imports showed increasing trends while semi-milled or wholly milled and brown rice imports showed decling trend. In 2009, around 94 percent of the total quantity of rice imports belongs to Semi-milled or wholly milled rice, whether or not polished or glazed followed by rice in the husk (paddy or rough) which accounts for about 5 percent. The remaining two broken rice and husked (brown) rice accounts for 1.07 and 0.05 percent respectively. The proportion of different forms of rice import in 2018 revealed that around 67 percent of the total quantity of imports belongs to Semi-milled or wholly milled rice, whether or not polished or glazed followed by rice in the husk (paddy or rough) which accounts for about 29 percent. The remaining two broken rice and husked (brown) rice accounts for 4.43 and 0.05 percent respectively.

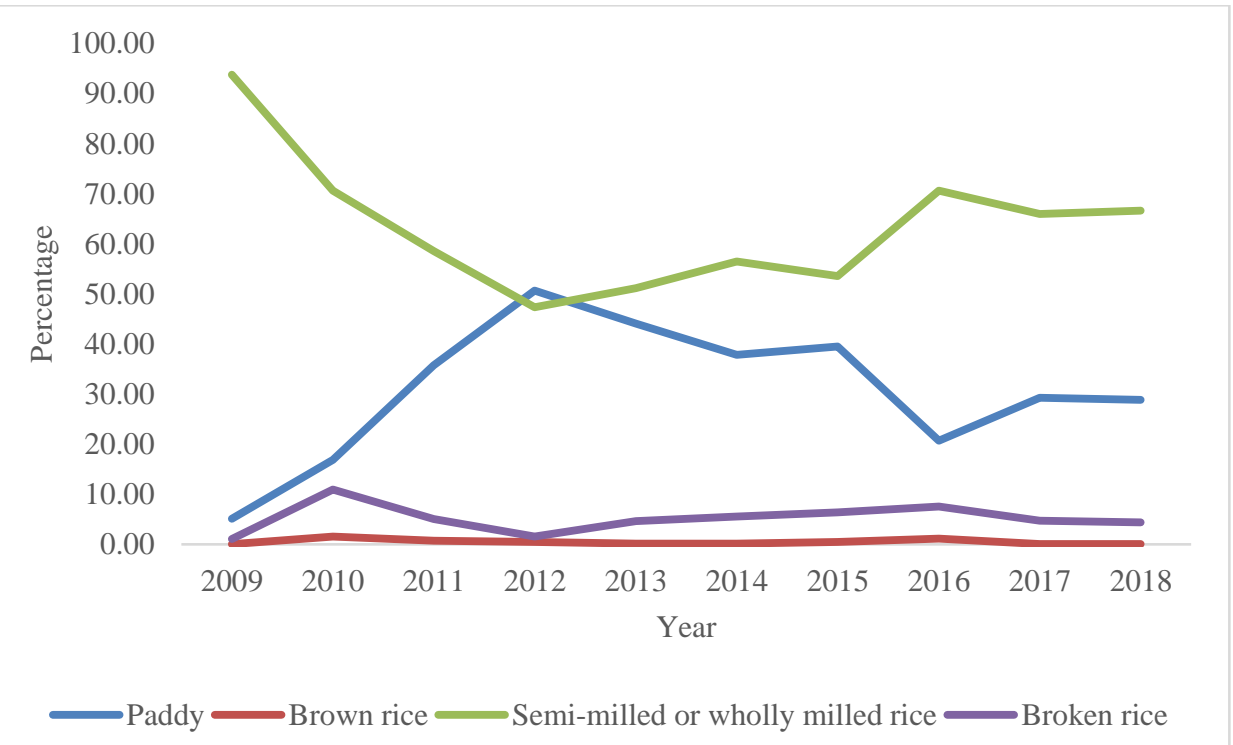

Figure 4. Trendline showing different forms of rice imports percentage from 2009 to 2018

Value and quantity of rice import growth rate in Nepal are shown in Table 4. The result revealed that the value of rice in the husk, Semi-milled or wholly milled rice, and Broken rice imports are increasing at the rate of 52.14, 36.70 and 52.01 percent per annum respectively and are statistically significant however husked brown rice is not statistically significant. Total rice import is increasing at the rate of 38.11 percent per annum and significant at 1 percent level.

Similarly, quantity of rice import growth rate revealed that rice in husk, Semi-milled or wholly milled rice and Broken rice are increasing at the rate of 36.98, 22.88 and 35.00 percent per annum respectively and are statistically significant however husked brown is not statistically significant. Total rice imports quantity are increasing at a rate of 24.48 percent per annum and significant at 1 percent level.

Table 4. Compound growth rate of value and quantity of rice import in Nepal from 2009 to 2018

\begin{tabular}{|c|c|c|c|c|c|c|}
\hline \multirow[t]{2}{*}{ Parameters } & \multicolumn{3}{|c|}{ Value } & \multicolumn{3}{|c|}{ Quantity } \\
\hline & Intercept & CGR & $\mathbf{R}^{2}$ & Intercept & CGR & $\mathbf{R}^{2}$ \\
\hline Rice in the husk (paddy or rough) & 19.15 & $\begin{array}{c}52.14 * * * \\
(0.006)\end{array}$ & 0.64 & 16.72 & $\begin{array}{c}36.98 * * \\
(0.015)\end{array}$ & 0.54 \\
\hline Husked (brown) rice & 15.90 & $\begin{array}{c}31.77 \\
(0.158)\end{array}$ & 0.23 & 13.20 & $\begin{array}{c}10.58 \\
(0.548)\end{array}$ & 0.05 \\
\hline $\begin{array}{l}\text { Semi-milled or wholly milled rice, } \\
\text { whether or not polished or glazed }\end{array}$ & 21.14 & $\begin{array}{c}36.70 * * * \\
(0.000)\end{array}$ & 0.91 & 18.17 & $\begin{array}{l}22.88 * * * \\
(0.000)\end{array}$ & 0.92 \\
\hline Broken rice & 17.23 & $\begin{array}{c}52.01 * * * \\
(0.001)\end{array}$ & 0.74 & 14.99 & $\begin{array}{c}35.00 * * * \\
(0.006)\end{array}$ & 0.63 \\
\hline Total rice import & 21.38 & $\begin{array}{c}38.11 * * * \\
(0.000)\end{array}$ & 0.86 & 18.57 & $\begin{array}{c}24.48 * * * \\
(0.000)\end{array}$ & 0.81 \\
\hline
\end{tabular}

Note: ***, **and * indicates Significance at 1, 5 and 10 percent level respectively. Figure in parentheses of CGR column indicates $P$-value 
Quantities of rice that are being imported to Nepal from different countries are illustrated by the transitional probability matrix in Table 5. The major rice exporting countries to Nepal are India, the USA, Thailand, Italy and China and remaining countries are grouped under Others. The result revealed that Nepal could get 99.9 percent previous year share from India. India may gain 88.8 percent from Italy, 100 percent from each of China and other countries. Nepal could get 99.4 percent previous year share from USA. Thailand may lost it share to USA at the tune of 100 percent. Similary, Italy may lost its share to Other countries at the rate of 11.2 percent. The direction of trade shows that the India and USA were more stable rice exporter while Thailand, Italy and China were less stable rice exporter to Nepal.

Table 5. Transitional probability matrix for different countries exporting volume of rice to Nepal from 2009 to 2018

\begin{tabular}{lrrrrrrr}
\hline Countries & India & & \multicolumn{1}{c}{ USA } & & \multicolumn{1}{c}{ Thailand } & Italy & \multicolumn{2}{c}{ China } & \multicolumn{2}{c}{ Others } \\
\hline India & $\mathbf{0 . 9 9 9}$ & 0.000 & 0.000 & 0.000 & 0.000 & 0.000 \\
\hline USA & 0.004 & $\mathbf{0 . 9 9 4}$ & 0.000 & 0.000 & 0.002 & 0.000 \\
\hline Thailand & 0.000 & 1.000 & $\mathbf{0 . 0 0 0}$ & 0.000 & 0.000 & 0.000 \\
\hline Italy & 0.888 & 0.000 & 0.000 & $\mathbf{0 . 0 0 0}$ & 0.000 & 0.112 \\
\hline China & 1.000 & 0.000 & 0.000 & 0.000 & $\mathbf{0 . 0 0 0}$ & 0.000 \\
\hline Others & 1.000 & 0.000 & 0.000 & 0.000 & 0.000 & $\mathbf{0 . 0 0 0}$ \\
\hline
\end{tabular}

\section{DISCUSSIONS}

The study revealed that the rice import quantity and value were increasing at the rate of 24.48 and 38.11 percent per annum respectively. From the literature review and field observations, the import of milled or semi-milled rice are mainly fine and aromatic rice. This shows that the import of premium (fine) rice has increased as CGR of value is higher than the quantity of rice imports in Nepal. The increased import and comsunption of fine rice in Nepal is also supported by earlier studies (Dhungel and Acharya 2017). Import of broken rice is also substantial; Adhikari et al (2018) stated that broken rice is used in beverage preparation and feeding to poultry. CBS (2016) reported that average consumption of coarse rice 92.8 $\mathrm{kg} /$ annum whereas the fine rice was 38.5 in 2015/16. By quantile groups, the consumption of fine rice is increasing from first (poorest) to fifth (richest) consumption group and opposite the case was found in coarse rice. For example, for fine rice, the first quintile group consumes $11.6 \mathrm{~kg}$ and the fifth quantile group consumes $80.2 \mathrm{~kg}$. For the coarse rice, the first quantile group consumes $106.6 \mathrm{~kg}$ while the fifth quantile group consumes $46.5 \mathrm{~kg}$ (CBS 2016). This shows the increasing level of income and preferences of Nepalese people towards different types of rice that have affected the types of rice imports in Nepal. In order to meet domestic requirements and reduce import, recently, government has been implementing specific rice promotion programs like fine and aromatic rice production, mega rice production, community seed banks and Prime Minister Agriculture Modernization Project (PMAMP) (Bhandari et al 2017).

With increasing in living standard, urbanization and changes in food culture towards the consumption of better quality rice grains, people have turned to consume fine and aromatic rice instead of coarse rice. Similarly, the Government of Nepal has not been able to develop and promote widely high yielding fine and aromatic rice varieties and hybrids to farmers. Hence, the domestic production of fine and aromatic rice is limited and able to meet increasing consumer demands in Nepal. Very few aromatic and fine rice varieties are being released till now. The officially released data of the Government of Nepal show that after the NARC establishment, till date 45 rice varieties have been released of which 17 were coarse, 10 were medium, 14 were fine and only 4 were fine and aromatic (SQCC, 2019). Recently, National Rice Research Program has initiated branding of fine rice varieties as Ram Dhan and Samba Masuli Sub-1 in coordination with private rice mill (www.narc.gov.np) that are in the state of promotion, but will take time to reach widely among consumers. Estimates by Prasad et al (2011) showed that the gap between the domestic production and direct demand by households for rice is likely to vary between 19 percent and 80 percent respectively. It appears that even with accelerated irrigation and increasing fertilizer supply, this deficit in rice would remain in the futre. However, technological inputs such as 
improved seeds of fine and aromatic rice could help increase the yield frontier and help in reducing this deficit in the future. In contrast with rice, there is likely to be a surplus production of wheat and maize.

The rice production and productivity are increasing at the rate of 1.69 and 2.20 percent per annum respectively which is very low as compared to import quantity and value growth rate. Gairhe et al (2018a) also found similar growth rate while analyzing dynamics of major cereals productivity in Nepal. However this growth rate is far below than the imports growth in Nepal.The growth rate of productivity can be increased through improved access to quality inputs such as seed, fertilizer and irrigation to farmers (Gairhe et al 2021, Gairhe et al 2018a, Timsina et al 2012). Average Per capita food consumption (kg per year) of coarse rice in rural area is 109 where as it was 65 in urban area (CBS 2016). This shows that the most of the coare rice is being supplied to rural areas of Nepal after massive increase in road network. Tripathi et al (2018) reported that trend of people switching from coarse grains to rice is rapidly increasing in hills and mountain areas with cheaper availability of rice from the increased road access. Gairhe et al (2020) opined that the galloping rice import was due to insufficient production to increased population and preference to fine rice and increased road access in hilly areas, and increased income level.The demand for rice will be increased in future. Tripathi et al (2018) reported that under high income growth and high population growth scenario, the paddy rice demand for 2035 is estimated at 10.26 million tons. This implies the required rice production is estimated at 12.83 million tons. This refers to the rice production increase of $185 \%$ from the current level.

Result of the transitional probabity matrix shows that India and USA were more stable rice exporters to Nepal while China, Thailand and Italy were less stable. This is because we heavily depend on India and USA than other countries. Among the differet countries share, India's share in quantity of rice import to Nepal is more than 95 percent in the study period. This is supported by earlier studies (Adhikari and Shrestha 2017). Similarly share from USA is also higher as compared to other countries

It is observed that Nepal is bound to spend huge sum of money to import rice and the graph surge exponentially in recent year. At the same time countries cultivable lands are increasingly becoming temporary as well as permanent fallow due to unavailability of labor from the youth out migration and high cost of labor. In addition, these land are being converted to roads and settlements due to unplanned urbanization and infrastructural development. Similar result of increment in the use of agricultural land to non-agricultural uses was found by earlier studies of Gairhe (2011) and; Gairhe et al (2018b).

Rice loss during consumption constitutes the major part of food loss in Nepal. The annual food loss or waste is estimated to be in range of 158,967.0 to 291,439.0 tonnes (Dhungel and Acharya 2017). Minimization of loss of rice during consumption certainly reduce the annual import of rice in Nepal. The consumption pattern of rice has changed from consuming coarse and medium to fine and aromatic rice in present days (Dhungel and Acharya 2017). Diversified products of rice have created employment opportunities and income gerneration (Adhikari et al 2018).

Integration of improved crop management practices with farmers management practices has potential to boost rice production and productivity. Adoption of best management practice in an integrated way is crucial to attain the productivity and a potential tool to minimize yield gap in rice (Alam et al 2013). This can be possible by intensifying irrigated rice systems to achieve a yield increase of more than $60 \%$ by the year 2025 (Cassman and Pingali 1995). Adoption of improved high yielding varieties are important for increasing productivity and reduce import. However, adoption of new modern rice varieties is low with the dominance of old varieties that are released before the year 2000 (Gauchan et al 2012; Gauchan 2017). Rehal et al (2017) reviewed different post harvest processes, miling treatments, factors and technology for improving quality as well as rice production. Percentage of head rice yield is the most important parameter in the milling. The grain behavior is dependent on moisture content during the harvest, drying mechanism, moisture content present during milling, milling conditions i.e. type of mill used, speed, temperature gradient, degree of polishing, variety of paddy, pretreatments given before milling etc. Pan et al (2008) concluded that the temparing process after the rapid infrared radiation heating and moisture removal is essential to achieve high rice milling quality and improve the 
amount of moisture removal during cooling. Natural cooling following the temparing treatment can be used to remove a significant amount of moisture while retaining high rice milling quality.

\section{CONCLUSION}

The country is importing rice in increasing trend and not being able to meet national demands despite some increase in rice production and productivity in the last one decade. Rice import quantity and value were increasing at a very high rate as compared to productivity growth in recent years. The higher growth rate of value than quantity showed that mainly import is concentrated on high-value fine and aromatic rice. The current production is not being able to meet the increasing demand of consumers in the country particularly the need of premium quality rice (fine and aromatic). This requires increasing productivity with increased use of high yielding hybrids and fine and aromatic rice in combination with use of other agricultural inputs (e.g. fertilizer and irrigation). Adoption of better grain quality rice varieties and their market promotion is one way to increase farmers' income and reduce huge import because premium grain quality rice varieties can fetch higher price in the market and meet increasing demand of consumers. Therefore, rice scientists and development professionals should develop and promote the production and marketing of premium quality rice varieties with better crop management and use of suitable associated inputs to meet increasing consumer demands. .

\section{ACKNOWLEDGEMENTS}

The authors are thankful to Ministries, National Planning Commission, Trade and Export Promotion Center, Centre Bureau of Statistics and NARC for providing relevant statistics.

\section{REFERENCES}

Adhikari SP and HK Shrestha. 2017. Rice value chain study in eastern Nepal. In: Rice Science and Technology in Nepal (MN Poudel, DR Bhandari, MP Khanal, BK Joshi, P Acharya and KH Ghimire, eds) Crop Development Directorate (CCD), Hariharbhawan and Agronomy Society of Nepal (ASoN) Khumaltar; pp. 618-625.

Adhikari SP, HK Shrestha and J Lamichhane. 2018. Analysis of rice marketing systems in eastern Nepal. In: Proceedings of the 12th National Outreach Research Workhop (Adhikari RC, D Bhandari, DR Khanal, TB Ghimire, MK Thakur, SP Vista and S Piya, eds) held on 18- 19 lune, 2017 at National Maize Research Program Rampur, Chitwan Nepal. Nepal Agricultural Research Council; pp.223-229.

Alam MM, MR Karim and JK Ladha. 2013. Integrating best management practices for rice with farmers' crop management techniques: A potential option for minimizing rice yield gap. Field Crops Res. 144: 62-68. DOI: $10.1016 /$ j.fcr.2013.01.010

Bagalkoti JB, A Bhat, J Megha, T Rijoy, H Siddu and NL Pavitra. 2019. A Markov chain analysis of cardamom export from India. J Pharmacogn Phytochem. 8(4):1573-1575.

Bhandari DR, PK Sanjel and S Adhikari. 2017. Policy review of paddy production in Nepal. In: Rice Science and Technology in Nepal (MN Poudel, DR Bhandari, MP Khanal, BK Joshi, P Acharya and KH Ghimire, eds) Crop Development Directorate (CCD), Hariharbhawan and Agronomy Society of Nepal (ASoN) Khumaltar; pp.719-734.

Cassman, KG and PL Pingali. 1995. Intensification of irrigated rice systems: Learning from the past to meet future challenges. GeoJournal. 35: 299-305. DOI: https://doi.org/10.1007/BF00989137

CBS. 2016. Annual Household Survey, National Planning Commission, Government of Nepal, Central Bureau of Statistics (CBS).

Dhungel S and P Acharya. 2017. Role of rice in food and nutrition security in Nepal. In: Rice Science and Technology in Nepal (MN Poudel, DR Bhandari, MP Khanal, BK Joshi, P Acharya and KH Ghimire, eds) Crop Development Directorate (CCD), Hariharbhawan and Agronomy Society of Nepal (ASoN) Khumaltar; pp.77-85.

Gairhe S and SV Reddy. 2012. Scenario of coffee in India-An overview. Res. J. Agric. Sci. 3(1): 259-261.

Gairhe S, H Shrestha and K Timsina. 2018a. Dynamics of major cereals productivity in Nepal. J. Nepal Agric. Res. Counc. 4:60-71. DOI: https://doi.org/10.3126/jnarc.v4i1.19691

Gairhe S, N Upadhyay, S Sapkota and MR Tiwari. 2018b. An investigation on land use dynamics and ecological implications in Nepal. Nepalese J. Agric. Sci. 16:5-12.

Gairhe S, RB Yadaw and K Timsina. 2020. Status of rice after NARC establishment in Nepal. In: Proceedings of 29th National Summer Crops Workshop (Bhandari D, HK Upreti, R Shrestha, J Tripati, HK Shrestha, KK Mishra, BK Joshi, AR Ansari, BP Tripathi, S Baidya, J Shrestha, M Tripati, P Paneru eds), held on 17- 
18 June, 2018 at Regional Agricultural Research Station (RARS), Lumle, Kaski, Nepal. Nepal Agricultural Research Council; pp.519-531

Gairhe S, KP Timsina, YN Ghimire, J Lamichhane, S Subedi and J Shrestha. 2021. Production and distribution system of maize seed in Nepal. Heliyon.7 DOI: https://doi.org/10.1016/j.heliyon.2021.e06775

Gairhe S. 2011. Land use dynamics in Karnataka: An economic analysis. Master Thesis. University of Agricultural Sciences, Dharwad, Karnataka, India.

Gauchan D and S Pandey. 2011. Is investment in rice research in Nepal adequate and balanced across production environments? Some empirical evidence. Q. J. Int. Agric. 50(4): 305-324.

Gauchan D, HK Pant, S Gautam and MB Nepali. 2012. Patterns of adoption of improved rice varieties and farm level impact in stress prone rainfed areas of Nepal. In: Pandey S, D. Gauchan, M. Malabayabas, M. BoolEmerick, B. Hardy (eds). Patterns of adoption of improved rice varieties and farm-level impacts South Asia. IRRI Book, Philippines 318p.

Gauchan D. 2017. Pattern of adoption and farmr level diffusion of modern rice varieties in Nepal. In: Rice Science and Technology in Nepal (MN Paudel, DR Bhandari, MP Khanal, BK Joshi, P Acharya and KH Ghimire, eds.) Crop Development Directorate (CDD) and Agronomy Society of Nepal (ASoN), Khumaltar; pp.744750.

Kaphle BD and DR Bist. 2017. Changing dietary pattern for consumption of rice in Nepalease society. In: Rice Science and Technology in Nepal (MN Poudel, DR Bhandari, MP Khanal, BK Joshi, P Acharya and KH Ghimire, eds) Crop Development Directorate (CCD), Hariharbhawan and Agronomy Society of Nepal (ASoN) Khumaltar; pp.100-105.

Kaphle BD, YS Bajgai, BP Khatiwada, Y Ghale and D Gauchan. 2020. Food Security Status and Challenges in Nepal: Policy Options and Choices. Book Chapter 1: "Sustainable, Sufficient, Safe and Healthy Food in Nepal: Principles and Practices of Food Security”. Nepalese Agricultural Professionals America (NAPA), USA.

MoALD. 2009. Statistical Information on Nepalese Agriculture. Ministry of Agriculture and Livestock Development, Government of Nepal.

MoALD. 2019. Statistical Information on Nepalese Agriculture 2074-75. Ministry of Agriculture and Livestock Development, Government of Nepal.

MoF. 2018. Economic Survey Report (2017-2018), Ministry of Finance, Government of Nepal, Singh Durbar, Kathmandu, Nepal.

Nepali Times. 2019. Nepal's rice economy. Nepali Times, Editorial. https://www.nepalitimes.com/editorial/nepals-rice-economy/

Padberg DI. 1962. The Use of markov processes in measuring changes in market structure. J. of Farm Econ. 44(1): 189-199. DOI: $10.2307 / 1235497$

Pan Z, R Khir, LD Godfrey, R Lewis, JF Thompson and A Salim. 2008. Feasibility of simultaneous rough rice drying and disinfestations by infrared radiation heating and rice milling quality. J. Food Eng. 84(3): 469479. DOI: $10.1016 /$ j.jfoodeng.2007.06.005

Prasad SK, H Pullabhotla, and AG Kumar. 2011. Supply and demand for cereals in Nepal 2010-2030. IFPRI Discussion Paper 01120, Environment and Production Technology Division.

Pudasainee A, TR Chaulagai, YN Ghimire and BP Chaulagain. 2018. Drivers of transition from export to import of rice in Nepal. Nepalese J. Agric. Sci. 17: 208-216.

Rehal J, GJ Kaur and AK Singh. 2017. Influence of milling parameters on head rice recovery: A review. Int.J.Curr.Microbiol.App.Sci. 6(10): 1278-1295. DOI: https://doi.org/10.20546/ijcmas.2017.610.152

Shrestha J, S Subedi, UKS Kushwaha and B Maharjan. 2021. Evaluation of rice genotypes for growth, yield and yield components. Journal of Agriculture and Natural Resources 4(2): 339-346. DOI: https://doi.org/10.3126/janr.v4i2.33967

Shilpa Shree J, SS Pandian and AK Natarajan. 2017. Changing direction of trade of dairy products in India - An application of markov chain analysis. Int. J. Livest. Res. 7(3): 57-62. DOI: 10.5455/ijlr.20170221051154

TEPC. 2018. Trade and Export Promotion Centre, Pulchowk, Lalitpur. Ministry of Industry, Commerce and Supplies , Government of Nepal. http://www.efourcore.com.np/tepcdatabank/commoditywise.php?txtmode=search

SQCC. 2019. Notified and denotified Crop Varieties in Nepal. Seed Quality Control Centre (SQCC), Ministry of Agricultural and Livestock Development (MoALD), Kathmandu, Nepal.

Timsina KP, KP Shrestha and S Pandey. 2012. Factors affecting adoption of new modern varieties of Rice in eastern Terai of Nepal. In: Proceeding of 4th Society of Agricultural Scientist-Nepal (SAS-N) conference held on 4-6 April, 2012 at Lalitpur. Nepal Agricultural Research Council (NARC) and Society of Agricultural Scientists (SAS-N), Nepal; pp.48-54.

Tripathi BP, HN Bhandari and JK Ladda. 2018. Rice Strategy for Nepal. Acta Sci. Agric. 2(9): 171-180.

Upadhyay N, KP Timsina, S Gairhe, S Sapkota, Y Acharya and S Khadka. 2019. Pulse in Nepal: A Retrospective Analysis. In: Proceedings of 30th National Winter Crops Workshop (D Bhandari, AK Gautam, R 
Shrestha, HK Upreti, YN Ghimire, KK Mishra, BK Joshi, AR Ansari, BP Tripati and P Paneru, eds), held on 15-16 February, 2017 at National Maize Research Program Rampur, Chitwan Nepal. Nepal Agricultural Research Council; pp.485-495.

||$------||-------1 \mid$ 